\title{
Relevance of Vocational High School Curriculum with Civil Engineering Vocational Education
}

\author{
Retno Mayasari ${ }^{1}$, Sri Handayani ${ }^{2}$, Harijadi Gunawan BW ${ }^{3}$, Azzah Balqis \\ Sabbah $^{4}$, Andri Setiyawan ${ }^{4}$ \\ \{retnomayasari@mail.unnes.ac.id\} \\ Department of Civil Engineering, Faculty of Engineering, Universitas Negeri \\ Semarang ${ }^{1,2,3,4,5}$.
}

\begin{abstract}
Educational components that play an important role in improving the quality of education are the curriculum. The curriculum serves as a tool and guidance on the progress of the learning process. Relevance of the curriculum is a major factor between education taught in college with the competencies expected in the workforce, in this case especially on the relevance of the curriculum between building engineering education and the eye curriculum Lessons taught at Vocational High School. This research aims to determine the level of relevance of vocational high school curriculum with civil engineering vocational education. The method of collecting data in this study is a questionnaire and documentation. The data analysis technique used is descriptive quantitative. Results of research percentage level relevance of vocational high school curriculum with civil engineering vocational education with the number of respondents 20 teachers from some vocational education in the Central Java region is $82.86 \%$.
\end{abstract}

Keywords: Relevance Curiculum, Vocational Education

\section{Introduction}

The curriculum is a series of planned program activities to achieve the expected competencies. "Curriculum planning is a process in which participants at many levels make decicions about what the purposes of learning ought to be, how those purposes might be carried out through teaching-learning situations, and whether the purposes and means are both appropiate and affective" (Beane, 1986), in planning curriculum for tertiary education and vocational high schools (SMK) must pay attention to several aspects, one of which is the aspect of competence expected in the world of work or competencies required by stakeholders. Curriculum planning in general must consider the needs of the community, the characteristics of learners, and the scope of knowledge in the hierarchy of knowledge (Taba dalam Saylor, et al., 1981). The curriculum in the study of building engineering education aims to be able to print the competencies of graduates as Vocational High School teachers in building engineering in a professional manner. Therefore this study discusses the relevance of the Building Engineering Education study curriculum with the Building Engineering SMK curriculum. 


\section{Method}

The type of research used is descriptive quantitative. Research on Professional Competence of Productive Teachers on Building Engineering Study Program graduates at PTB UNNES to find out how much the level of professional competence of technical teachers graduated from the UNNES PTB study program.

The method used is the method used is a questionnaire / questionnaire and documentation. The research was conducted at several vocational schools in Central Java including the SMK N 1 Kedungwuni, SMK N 1 Adiwerna Tegal, SMK N 1 Blora, SMK 2 Cilacap, SMK N 2 Kebumen, SMK N 2 Sragen, SMK Ganeshatama Boyolali, SMK Sunan Kalijaga, SMK N 1 Blora. Thenonprobability. The sampling technique in this study was carried out by nonprobability sampling technique, there is a saturated sampling technique, which is a sampling technique if all members of the population are sampled (Sugiyono, 2010: 124). This sampling technique is used when facing a relatively small population. The number of respondents in this study were 20 people who were alumni of the PTB UNNES study program from 2008 to 2011 with a total of 14 questionnaire questions, with the following assessment criteria:

Table 1. The descriptive criteria of the curriculum relevance percentage

\begin{tabular}{lll}
\hline No & Interval & Relevance Level \\
\hline 1 & $84 \%-100 \%$ & Very relevant \\
2 & $67 \%-68 \%$ & Relevant \\
3 & $52 \%-52 \%$ & Slightly relevant \\
4 & $36 \%-51 \%$ & Irrelevant \\
5 & $20 \%-35 \%$ & Very irrelevant \\
\hline
\end{tabular}

\section{Results and Discussion}

The results of the analysis showed one competence / curriculum at vocational schools that was not relevant with the 2008 curriculum of the Civil Engineering Vocational Education Department, UNNES. The 2008 curriculum of the Civil Engineering Vocational Education Department, UNNES has 43 subjects with these following categories: Personality Development Subjects (MPK), Scientific and Skills Subjects (MKK), Productive Skills Subjects (MKB), Productive Behavior Subjects (MPB), Community Behavior Subject (MBB). Theexisting curriculum of Civil Engineering Vocational Education Department was the 2013 curriculum. It has the different names for each skill program and skills competencies. However, the content of the coverage is similar to that of the previous curriculum . 
Table 2. The results of curriculum relevance

\begin{tabular}{lll}
\hline No & Relevance Level & Percentage \\
\hline 1 & Very relevant & $82.86 \%$ \\
2 & Relevant & 0 \\
3 & Slightly relevant & 0 \\
4 & Irrelevant & $17.14 \%$ \\
5 & Very irrelevant & 0 \\
\hline
\end{tabular}

The data were obtained from 20 respondents who have become teachers in Civil Engineering Vocational Education Department. The data showed the percentage of relevance between 2008 curriculum of Civil Engineering Vocational Education Department, UNNES with the curriculum of the vocational schools is $82.86 \%$. It is categorized as very relevant. $17.14 \%$ do not respond to the item. The relevance results of the Curriculum Relevance of Vocational High School Curriculum with Civil Engineering Vocational Education with a percentage of 82.86 is relevant.

\section{References}

[1] Arikunto, S. (2006). Prosedur Penelitian: Suatu pendekatan Praktik. Jakarta: Rineka Cipta.

[2] Beane, J.A. \&Lipka, R.P. 1986. Self Concept, Self Esteem and The Curiculum. Teacher College Press. New York

[3] Douwe Beijaard*, Paulien C. Meijer, Nico Verloop. 2004. Reconsidering research on teachers' professional identity. Journal Teaching and Teacher Education 20 (2004) 107-128.

[4] Finch, \& Crunkilton. (1992). Curriculum development in vocational and technical education. Planning, content and implementation. Fourth edition. Virginia: Polytechnic Institute and State University.

[5] Law number 14 of 2005. Concerning Teachers and Lecturers.

[6] Saylor, J.Galen; Alexander, William M, dan Lewis, Athur J, (1981), Curriculum Planning for better Teaching and Learning, New York: Holt, Rinehartand Wiston. 